\title{
Penyuluhan Pencegahan RisikoStunting 1000 Hari Pertama Kehidupan pada Generasi Muda
}

\author{
${ }^{1}$ Marni $^{*},{ }^{2}$ Nita Yunianti Ratnasari \\ ${ }^{1}$ Keperawatan, Universitas Duta Bangsa Surakarta, Indonesia \\ Keperawatan Komunitas, Akademi Keperawatan Giri Satria Husada, Wonogiri, Indonesia \\ *Corresponding Author \\ J1. Tentara Pelajar No 01, Giriwono, Wonogiri. Telp/Fax 0273322610 \\ E-mail: marnigsh020@gmail.com \\ Received: \\ Revised: Accepted: \\ Published: \\ 14 March 2021 \\ 06 October $2021 \quad 12$ October 2021 \\ 23 November 2021
}

\begin{abstract}
ABSTRAK
Masa pandemi Covid-19 yang sampai saat ini masih berlanjut maka pemerintah membuat kebijakan PSBB /PPKM Mikro. Kebijakan ini menyebabkan masalah pada perubahan sosial ekonomi. Banyak orang miskin mendadak akibat pandemi, sehingga tidak mampu mencukupi nutrisi/gizi yang bisa mengakibatkan terjadinya stunting pada anggota keluarganya, termasuk keluarga yang mempunyai anak bawah dua tahun (baduta) dan ibu hamil, kurangnya pengetahuan dalam memberikan nutrisi yang tepat pada ibu hamil, menyusui dan anak baduta juga bisa menyebabkan stunting. Perlu peran aktif dari petugas kesehatan namun saat ini petugas mempunyai beban berat dalam menghadapi masalah kesehatan covid-19, sehingga perguruan tinggi diharapkan berkontribusi membantu pemerintah dalam mencegah terjadinya stunting. Tujuan kegiatan: meningkatkan pengetahuan generasi muda tentang cara mencegah terjadinya stunting, memotivasi generasi muda agar berkontribusi dengan memberi penyuluhan kepada masyarakat, terutama yang mempunyai keluarga dengan ibu hamil, ibu menyusui dan anak baduta, berperilaku hidup bersih dan sehat dengan tidak merokok,tidak mengkonsumsi narkoba, tidak melakukan seks bebas sehingga tidak muncul kehamilan yang tidak diharapkan. Metode penyuluhan dalam kegiatan ini adalah dengan ceramah, diskusi dan tanya jawab, memberikan kuesioner sebelum diberi penyuluhan untuk mengetahui pengetahuan generasi muda tentang pencegahan stunting peran generasi muda, dan setelah diberi penyuluhan diberi kuesioner lagi untuk mengetahui peningkatan pengetahuan pada generasi muda tersebut. Hasil: Skor nilai mean pengetahuan sebelum diberikan penyuluhan adalah 49,3, skor setelah diberikan penyuluhan adalah nilai mean 75,2 sehingga terjadi kenaikan skor mean nilai 25,9. Kesimpulan: Penyuluhan kesehatan ini terbukti meningkatkan pengetahuan para generasi muda dalam mencegah terjadinya stunting.
\end{abstract}

Kata kunci: Generasi muda; Stunting

\section{ABSTRACT}

Covid-19 pandemic period until now still persists then the government makes policy PSBB / PPKM Micro. This policy causes problems for socio- economic change. Many people are suddenly poor due to the pandemic, so they are unable to fulfill their nutrition / nutrition which can lead to stunting in their family members including families who have a child under two years (baduta) and the mother was pregnant, the lack of knowledge in giving nutrients are right on mothers pregnant, breastfeeding and child baduta also can cause stunting. Health workers need an active role, but currently officers have a heavy burden in dealing with covid-19 health problems, so universities are expected to contribute to assisting the government in dealing with Covid-19 health problems. The purpose of activities: improving knowledge generation youth about how to prevent the occurrence of stunting, 


\begin{abstract}
motivate generations of youth in order to contribute to give counseling to the community, especially that having a family with a mother pregnant. Mother breastfeeding and child baduta, behaves live clean and healthy by not smoking, not taking drugs, do not pass up sex -free so it does not appear a pregnancy that was not expected. Methods of counseling in activity this is by lectures, discussions and question and answer, giving a questionnaire before given counseling to know the knowledge of adolescents on the prevention of stunting and the role of the generation of young, and after a given extension by the questionnaire again to determine the increase in knowledge on adolescent that. Results: Scores grades mean knowledge before given counseling is 49.3, scores after a given extension is the value of the mean of 75.2 to happen hike score mean value of 25.9. Conclusion: This health education is proven to increase the knowledge of adolescents in preventing stunting.
\end{abstract}

Keywords: Golden generation; Stunting

\title{
PENDAHULUAN
}

Pandemi Covid-19 yang melanda bangsa ini sampai saat ini belum bisa diatasi, setiap hari semakin bertambah orang yang menderita Covid-19, sehingga Pemerintah mengambil kebijakan untuk Pembatasan Sosial Berskala Besar (PSBB) (Efrizal, 2020). Selain itu, adanya PSBB, atau istilah lain adalah Pemberlakuan Pembatasan Kegiatan Masyarakat (PPKM Mikro) diperpanjang sampai 22 Maret 2021 (Farisa, 2021). Pembatasan ini mengakibatkan perubahan sosial ekonomi (Efrizal, 2020), sebagian aktivitas terhenti, sehingga menurunkan pendapatan masyarakat, meningkatkan rasa cemas dan kekawatiran bagi sebagian orang, menurunkan akses pelayanan kesehatan dan sebagainya. Kebijakan untuk membatasi aktivitas diluar rumah, menjaga jarak, larangan untuk berkerumun, berakibat menurunkan layanan kesehatan bagi Ibu hamil dan anak, sehingga petugas kesehatan mengalami kesulitan untuk memantau pertumbuhan dan perkembangan anak serta kesehatan ibu hamil. Kondisi ekonomi yang semakin sulit, menyebabkan pasangan usia subur semakin enggan menggunakan alat kontrasepsi, sehingga kondisi ini meningkatkan angka kehamilan. Kenaikan jumlah kehamilan yang tidak dikehendaki karena tidak sempat mengakses layanan KB dan maraknya seks bebas yang dilakukan oleh pasangan remaja yang belum cukup siap juga menjadi masalah yang banyak terjadi di Indonesia. Kehamilan seperti ini bisa mengancam peningkatan angka stunting atau kekerdilan, angka kematian ibu, dan angka kematian janin, disebabkan adanya kurangnya asupan nutrisi saat hamil, bayi masih dalam kandungan, menyebabkan bayi lahir karena memiliki kualitas rendah, jika kekurangan asupan nutrisi terjadi terus menerus sampai 1000 hari pertama, maka bisa mengakibatkan terjadinya stunting.

Stunting adalah masalah kurang gizi pada anak yang berlangsung lama (bisa dimulai dari saat masih dalam kandungan) yang menyebabkan gangguan pertumbuhan anak yaitu tinggi badan anak lebih rendah dari seusianya (kerdil) (Izwardy, 2020). Stunting merupakan masalah kesehatan yang perlu segera diatasi. Indonesia merupakan negara tertinggi ketiga di Asia Tenggara setelah Timor Leste dan India (Teja, 2019). Organisasi Kesehatan Dunia (WHO) menempatkan Indonesia sebagai negara ketiga dengan kasus tertinggi di Asia. Kejadian stunting di Indonesia mencapai 30,8\%, lebih tinggi dari dunia yaitu 22,2\%, WHO menentukan masalah kekurangan gizi suatu negara tidak boleh lebih dari 20\% (Budiastutik \& Rahfiludin, 2019). 24 juta anak di Indonesia beresiko kekurangan gizi pada masa pandemic covid-19. Stunting disebabkan dari berbagai faktor, diantaranya adalah kurangnya asupan energi, riwayat durasi penyakit infeksi, berat badan, lahir rendah, tingkat pendidikan ibu dan tingkat pendapatan keluarga (Hadi et al., 2019). Kekurangan gizi pada bayi bisa menyebabkan gizi buruk, yang berdampak pada gangguan psikomotor, kognitif dan sosial, serta secara klinis terjadi gangguan tumbuh kembang, salah satunya adalah tinggi badan lebih pendek dari usia sebenarnya (kerdil) (Febriani et al., 2018). Dampak lain dari stunting ini adalah derajad Kesehatan dan gizi anak Indonesia masih memprihatinkan, padahal anak anak tersebut nanti yang akan mengisi pembangunan di Indonesia, 
jika para generasi mempunyai kualitas Sumber Daya Manusia yang kurang optimal, maka Bangsa Indonesia akan menjadi bangsa yang lemah. Sehingga perlu kebijakan untuk meningkatkan pengetahuan masyarakat dalam hal memberikan nutrisi yang bergizi pada bayi/anak dan ibu hamil. Langkah yang harus dilakukan untuk mengatasi terjadinya stunting adalah dengan pemberian Pendidikan yang berkualitas, pemberian nutrisi yang bergizi dan pengembangan EST (Eco Support Theory) (Hadi et al., 2019). Stunting bisa dicegah dengan cara sejak janin masih dalam kandungan diberikan nutrisi yang cukup sampai anak lahir hingga anak usia 2 tahun (Teja, 2019). Upaya yang dilakukan untuk mencegah kejadian stunting diberikan kepada ibu hamil, ibu bersalin, balita, anak usia sekolah, remaja, dan dewasa muda(Promosi Kesehatan, 2020). Pada Ibu Hamil dan bersalin, upaya yang diberikan adalah intervensi 1000 hari pertama kehidupan, menyelenggarakan program pemberian makanan tinggi kalori, protein dan mikronutrien, penyuluhan dan pelayanan konseling Inisiasi Menyusui Dini dan ASI ekslusif, pelayanan KB. Pada anak balita adalah pemantauan tumbuh kembang balita, pemberian makanan tambahan (PMT), pelayanan kesehatan yang optimal, pada remaja dengan meningkatkan penyuluhan untuk perilaku hidup bersih dan sehat (PHBS), pola gizi seimbang, tidak merokok, tidak mengkonsumsi narkoba dan tidak melakukan seks bebas, Pendidikan Kesehatan reproduksi (Promosi Kesehatan, 2020). Remaja mempunyai andil yang penting dalam mencegah kejadian stunting, untuk itu remaja perlu diberikan penyuluhan agar bisa berpartisipasi dalam membantu pemerintah menurunkan kejadian stunting.

Dalam rangka ikut berkontribusi pada kebijakan pemerintah dalam menekan angka stunting, Departemen Kesehatan GenBI Jakarta mengadakan program kerja yang bertujuan untuk memberikan pengetahuan mengenai pola asuh asupan gizi orangtua kepada anak, yaitu menyelenggarakan Webinar Edukasi Stunting" Prevent Stunting for Golden Generation”. Selain itu, intervensi kepada anak yang tumbuh remaja, saat akan menikah, dan akan melahirkan juga perlu dilakukan. Jika memang anak terindikasi stunting, orangtua perlu segera berobat ke pelayanan kesehatan terdekat agar stunting anak tidak berlarut-larut.

Tujuan dalam kegiatan ini adalah untuk memberikan pengetahuan kepada para generasi muda khususnya mahasiswa yang bisa berkontribusi membantu pemerintah dalam mencegah terjadinya stunting dengan cara memberikan / menyebarkan informasi mengenai pencegahan stunting, Pendidikan tentang gizi dan cara menyiapkan makanan sehat bagi anak, pada ibu hamil, setelah mengetahui pencegahan stunting, diharapkan mahasiswa bisa menjadi role model/memberikan Pendidikan kepada masyarakat yang mempunyai bayi, anak balita, dan ibu hamil, selain itu diharapkan mahasiswa juga rajin belajar untuk meningkatkan kompetensi dan ilmu dalam berbagai bidang sehingga setelah lulus bisa terjun kemasyarakat untuk berperan aktif dalam mengisi pembangunan bangsa dan negara sesuai dengan kompetensi yang dimilikinya. Harapan kedepan, semua anak tumbuh sehat sehingga menjadi generasi muda yang berkarakter dan tanggung serta memiliki daya saing.

\section{METODE}

Pelaksanaan kegiatan pengabdian / penyuluhan diawali dengan koordinasi pengabdi dengan para pengurus GenBI Jakarta, yang difasilitasi oleh saudari Nurul Salamah yang merupakan mahasiswa Universitas Negeri Jakarta Fakultas Ekonomi, yang tergabung dalam anggota Komunitas GenBI Jakarta. Pengurus GenBI mempunyai permasalahan tentang kurangnya pengetahuan tentang pencegahan Stunting, dan permasalahan tersebut sesuai dengan kompetensi Pengabdi, sehingga setelah melalui beberapa rapat koordinasi dan perijinan, maka kegiatan webinar bisa dilaksanakan sesuai rencana. Rancangan kegiatan pengabdian masyarakat ini dilakukan dengan cara memberikan penyuluhan kesehatan tentang pencegahan stunting pada masa generasi emas (golden periode generation). Khalayak sasaran pada kegiatan penyuluhan ini adalah para mahasiswa baik laki-laki maupun perempuan, dari berbagai perguruan tinggi yang tersebar di berbagai wilayah di Indonesia, dan ada beberapa mahasiswa dari negara tetangga Timor Leste. Kegiatan ini bertempat dikediaman masing-masing peserta, menggunakan aplikasi 
Zoom Meeting, dilaksanakan pada hari Sabtu, tanggal 17 Oktober 2020, mulai pukul 09.00 dan berakhir pada pukul 12.00, dengan metode ceramah dan diskusi (Marni, 2020). Kegiatan ini menggunakan metode ceramah terkait bagaimana cara melakukan pencegahan pada anak agar tidak terjadi stunting, peran generasi muda dalam membantu pemerintah untu menrunkan kejadian stunting di Indonesia. Media yang digunakan dalam kegiatan penyuluhan ini adalah Laptop, web cam, dan headseat, sedangkan peserta ada yang menggunakan laptop, ataupun Hp Android.

Kegiatan ini terdiri dari 3 tahapan. Tahapan pertama adalah perkenalan, kedua tahap kerja dengan memberikan penyuluhan/ceramah dan diskusi dan tahap ketiga adalah tahap terminasi/evaluasi. Tahap/fase perkenalan, disini ketua pengabdian mengadakan perkenalan dengan panitia dari GenBI, dan dengan semua peserta penyuluhan yang sudah tergabung dalam link Zoom, menjelaskan tujuan pengabdian, memvalidasi dan menanyakan kesiapan peserta yang terdiri dari mahasiswa dari berbagai perguruan tinggi yang tersebar di berbagai wilayah. Setelah semua siap, tim pengabdi mulai melakukan fase kerja, dengan cara memberikan pertanyaan terkait stunting, pencegahan dan peran generasi muda untuk berkontribusi dalam menurunkan kejadian stunting di Indonesia. Setelah memberikan pertanyaan, pengabdi masuk dalam kegiatan inti, yaitu memberikan penyuluhan tentang pencegahan stunting untuk masa emas, peran generasi muda dalam menurunkan / mencegah terjadinya stunting di Indonesia. Penyuluhan diberikan dengan metode ceramah dan diskusi, tanya jawab terkait stunting. Peserta sangat antusias dalam sesi ini, memperhatikan materi penyuluhan dan aktif berdiskusi, tim pengabdian juga memberikan kesempatan peserta untuk bertanya dan kami menjawab pertanyaan dari peserta, peserta sangat antusias, namun karena terbatasnya waktu, tidak semua peserta bisa menanyakan secara langsung kepada pemateri, sebagai gantinya, peserta bertanya dikolom chat. Gambar 1 dibawah ini adalah situasi saat pembukaan oleh Ketua GenBI Jakarta Saudara Refi Muhammad Syafei

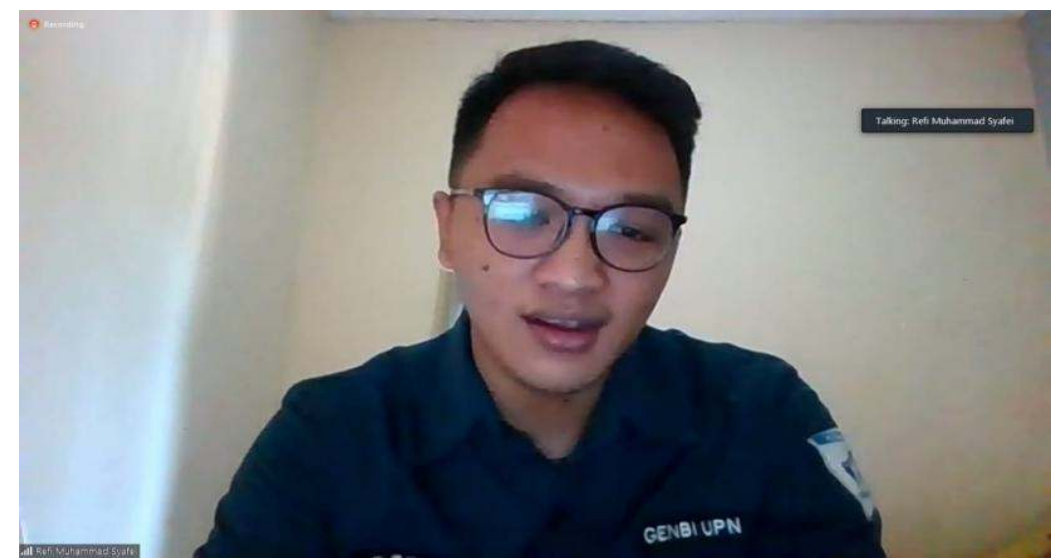

Gambar 1. Penyampaian kata pengantar/ Pembukaan oleh Ketua GenBI Jakarta 


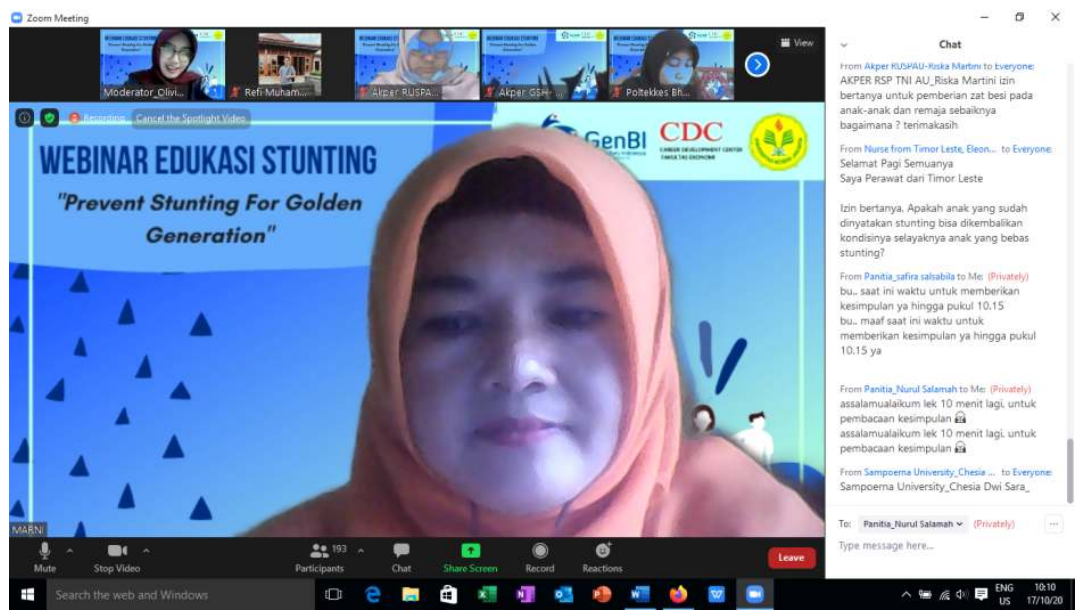

Gambar 2. Penyampaian materi pencegahan Stunting .

Gambar 2 adalah saat tim pengabdi memberikan materi terkait pencegahan stunting dan peran generasi muda dalam membantu pemerintah mencegah terjadinya stunting. Peserta penyuluhan sangat antusias mengikuti kegiatan penyuluhan tersebut, dan mengatakan bahwa materi yang disampaikan sangat jelas dan menambah wawasan dalam mencegah terjadinya stunting. Peserta juga semangat untuk membantu pemerintah memberi penyuluhan dan juga mau berperilaku hidup bersih dan sehat.

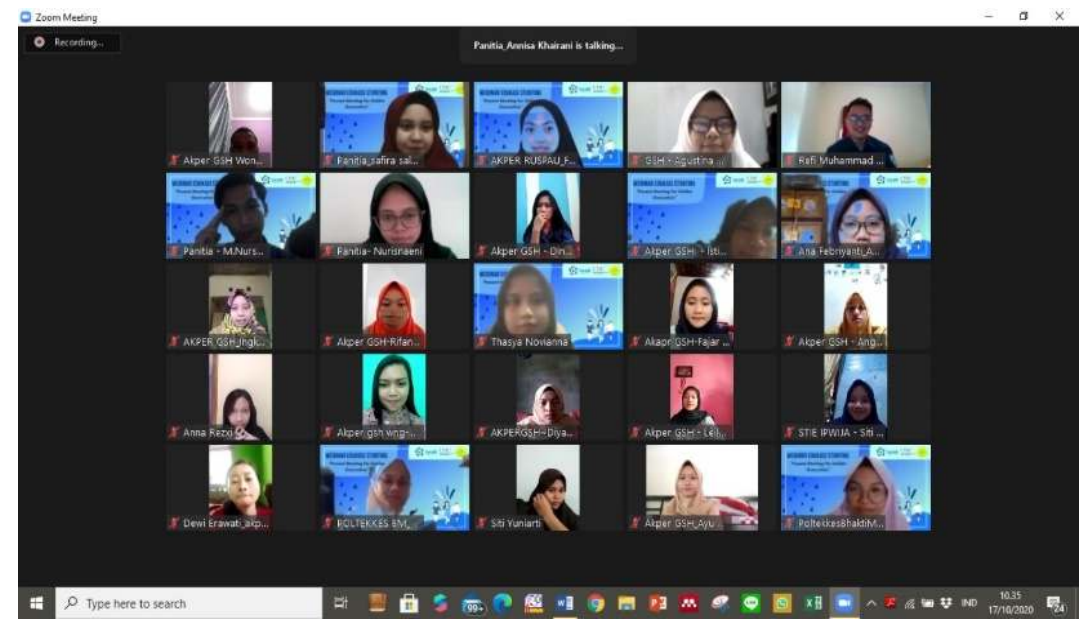

Gambar 3. Para Peserta webinar Edukasi Pencegahan Stunting

Gambar 3 adalah fase terakhir/terminasi, dimana pada fase diadakan evaluasi, evaluasi subyektif dan obyektif. Evaluasi subyektif dengan cara menanyakan materi penyuluhan yang telah disampaikan, menanyakan bagaimana perasaan peserta setelah diberikan materi penyuluhan, dan evaluasi obyektif dengan menanyakan materi penyuluhan yang telah disampaikan dengan memberi kesempatan pada peserta untuk mengisi kuesioner evaluasi.

\section{HASIL DAN PEMBAHASAN}

\section{Gambaran Penyelenggaraan Webinar}

Kegiatan pengabdian masyarakat ini terlaksana berkat Kerjasama yang baik antara Pengabdi /Pemateri dan Komunitas Generasi Baru Indonesia (GenBI) Jakarta). Komunitas GenBI adalah komunitas penerima beasiswa Bank Indonesia yang dibentuk di seluruh perguruan tinggi di Indonesia. Komunitas GenBI diresmikan pada tanggal 17 Agustus 2011. Para mahasiswa penerima beasiswa Bank Indonesia ini difasilitasi dalam wadah Komunitas GenBI, selain 
mendapatkan biaya untuk Pendidikan, tunjangan dan biaya hidup, mahasiswa tersebut juga mendapat pelatihan secara berkala, terarah dan terencana guna meningkatkan kompetensi individu dalam mengembangkan karakter dan jiwa kepemimpinan agar menjadi insan unggul dan berdaya saing (Indonesia, 2021). Mahasiswa merupakan generasi muda yang menjadi faktor penentu bagi peradaban, kemajuan perkembangan dan kesejahteraan suatu bangsa. Sumber Daya Manusia (SDM) yang terdidik dan berilmu pengetahuan dan berkualitas akan menjadi aset dalam pembangunan bangsa dan negara pada masa yang akan datang (Indonesia, 2021). Dalam rangka meningkatkan kemampuan kepemimpinan dan berkontribusi dalam pencegahan stunting, para mahasiswa yang tergabung dalam komunitas GenBI mengadakan webinar edukasi stunting, kegiatan ini bertujuan untuk meningkatkan kemampuan dan pengetahuan dalam mencegah terjadinya stunting dan perilaku hidup bersih dan sehat (PHBS).

\section{Pengetahuan tentang Pencegahan Stunting}

Pelaksanaan webinar / penyuluhan tentang pencegahan stunting via zoom meeting dilaksanakan hari Sabtu tanggal 17 Oktober 2020 pukul 09.00 sampai selesai. Panitia penyelenggara adalah Komunitas GenBI Jakarta yang terdiri dari mahasiswa putra dan putri dari beberapa kampus di Jakarta yang mendapat beasiswa dari Bank Indonesia, yaitu Universitas Negeri Jakarta, Universitas Pembangunan Nasional Jakarta, dan UNSIKA. Setelah melakukan koordinasi antara Pengabdi dan panitia, dengan berbagai persiapan yang dilakukan bersama oleh pengabdi dan panitia maka kegiatan webinar berjalan lancar dan sangat menarik bagi para peserta. Peserta webinar adalah mahasiswa dari 26 perguruan tinggi dan 1 orang dari kementrian kesehatan Timor Leste, total jumlah peserta 201 mahasiswa/orang. Selama pelaksanaan webinar, peserta sangat antusias mengikuti kegiatan mulai dari pembukaan webinar sampai dengan selesai. Pemberi materi dengan semangat memberikan materi penyuluhan/webinar, menjelaskan pokok pokok bagian yang penting dan harus diketahui oleh peserta, dan memberi kesempatan kepada peserta untuk bertanya terkait pencegahan stunting dan peran generasi muda dalam berkontribusi untuk mencegah kejadian stunting di Indonesia. Peserta webinar/penyuluhan mengatakan bahwa materi yang disampaikan sangat menarik, sangat bermanfaat sehingga mereka ingin mendapatkan materi penyuluhan seperti ini lagi, dan minta tambahan waktu agar pembahasan materi lebih lama dan mendetail. Selain antusias dalam mengikuti kegiatan, mereka juga aktif bertanya dan pengabdi menjawab pertanyaan dari peserta. Peserta meminta sering-sering saja diadakan acara seperti ini lagi. Generasi muda mempunyai peranan penting dalam pembangunan, begitu pula dalam menciptakan calon generasi yang berkualitas dan berdaya saing. Seperti penelitian sebelumnya yang mengatakan bahwa stunting merupakan masalah kesehatan yang menjadi prioritas untuk menciptakan SDM Indonesia yang berkualitas (Lawaceng \& Rahayu, 2020). Untuk itu para mahasiswa mempunyai tugas berkontribusi agar mempunyai perilaku hidup besih dan sehat, tidak merokok, menggunakan narkoba, melakukan seks bebas sehingga tidak terjadi kehamilan yang tidak direncanakan yang bisa menimbulkan masalah stunting. Untuk mewujudkan tujuan tersebut maka para mahasiswa mengadakan acara webinar yang berisi penyuluhan Kesehatan tentang pencegahan stunting. Berikut ini adalah sebaran perguruan tinggi yang mahasiswa nya menjadi peserta dalam kegiatan webinar.

Tabel 1. Peserta Webinar / Penyuluhan Pencegahan Stunting

\begin{tabular}{llc}
\hline No & \multicolumn{1}{c}{ Nama Perguruan Tinggi } & Jumlah Peserta \\
\hline 1 & Universitas Negeri Jakarta & 67 \\
2 & Akper Giri Satria Husada Wonogiri & 49 \\
3 & Poltekes Bakti Mulia Sukoharjo & 25 \\
4 & GenBI UNJ & 7 \\
5 & GenBI UPN & 7 \\
6 & STIE IPW I JAKARTA & 6
\end{tabular}


Indonesian Journal of Community Services

Volume 3, No. 2, November 2021

http://jurnal.unissula.ac.id/index.php/ijocs

DOI: http://dx.doi.org/10.30659/ijocs.3.2.116-125

Universitas Pembangunan Nasional Jakarta 5

8 Akper Insan Husada 5

9 Universitas Duta Bangsa Surakarta 4

10 Akper RSP TNI AU 3

11 Stikes Mitra Ria Husada 2

12 STIKes Santo Borromeus Bandung, Jawa Barat 2

13 Universitas Islam As-Syafi'iyah 2

14 Stikes Estu Utomo 2

15 Universitas Sebelas Maret Surakarta 2

16 Stikes Mitra Ria Husada 2

17 GenBI UNSIKA 1

18 STAN 1

19 STIKESMUS 1

20 UNISMA 1

21 Stikes Widya Dharma Husada 1

22 Stikes Duta Gama Klaten 1

23 Kementerian kesehatan Timor Leste, Vera-Cruz 1

$24 \quad$ Universitas Pamulang 1

25 Universitas Singaperbangsa Karawang 1

26 Universitas Kusuma Husada Surakarta 1

27 Universitas Nahdlatul Ulama Purwokerto 1

$\begin{array}{ll}\text { TOTAL } & 201\end{array}$

Tabel 1 merupakan sebaran peserta dari berbagai perguruan tinggi di Indonesia, Semua peserta adalah mahasiswa, yang berusia rata-rata 20 tahun, tergolong dalam usia remaja-dewasa muda, dan hanya satu yang merupakan pegawai kementerian kesehatan di Timor leste.

Generasi muda mempunyai peranan penting dalam mengisi pembangunan, untuk itu para generasi muda harus mempunyai pengetahuan yang cukup dan kompeten sesuai dengan keahliannya, namun tidak menutup kemungkinan, bahwa untuk menjadi konselor Kesehatan/kader kesehatan tidak harus kuliah sesuai program studi nya, jadi bisa dari jurusan/program studi apa saja, yang penting ada kemauan dan kemauan untuk menambah ilmu terkait stunting dan pencegahannya, sehingga generasi muda tersebut bisa memberikan penyuluhan/menyebarkan informasi terkait bagaimana cara yang bisa dilakukan untuk meningkatkan asupan gizi pada ibu hamil, menyusui dan anak bawah dua tahun (baduta). Penelitian sebelumnya yang telah dilakukan oleh Marni bahwa penyuluhan kesehatan mampu meningkatkan pengetahuan (Marni, 2020), sehingga walaupun mahasiswa tersebut tidak kuliah di program studi kesehatan, apabila mau dan sering mengikuti penyuluhan kesehatan tentang pencegahan stunting, maka dia akan mengetahui bagaimana cara pencegahan stunting tersebut dan bisa memberi informasi seperti kader kesehatan yang ada dimasyarakat, walaupun berbagai jurusan ilmu yang berbeda, namun mereka bisa menjadi kader kesehatan asal ada kemauan untuk belajar dan mengikti penyuluhan /pelatihan tentang kesehatan.

Untuk mewujudkan tujuan tersebut, maka para generasi muda tersebut aktif menambah pengetahuan, dengan cara mengikuti webinar ini. Dengan menambah pengetahuan dengan cara mengikuti berbagai kegiatan seperti webinar, seminar, penyuluhan, workshop, lokakarya, maka akan meningkatkan pengetahuan orang tersebut. Penelitian sebelumnya yang telah dilakukan oleh Zulaikhah bersama timnya, mengatakan bahwa pengetahuan merupakan salah satu faktor predisposisi yang bisa merubah perilaku (Zulaikhah et al., 2019), sehingga untuk mengubah perilaku yang baik dengan menjauhi pemakaian narkoba, menerapkan pola hidup bersih dan sehat (PHBS), gemar menjadi penyuluh/pemberi informasi, maka seseorang harus diberi pengetahuan. 
Sebelum mengikuti webinar / pemaparan materi, pemateri memberikan pertanyaan dengan mengisi kuesioner tentang pengertian stunting, faktor resiko terjadinya stunting, penyebab, ciriciri anak yang menderita stunting, bahaya yang timbul akibat stunting, peran generasi muda sebagai golden generation, kebutuhan gizi ibu hamil, cara mengatasi anemia pada ibu hamil, kebutuhan gizi pada pertumbuhan dan perkembangan balita, makanan bayi usia 0-6 bulan, jenisjenis MP-Asi, Makanan untuk bayi dan baduta, masalah dalam pemberian makanan bayi, Nutrisi pada bayi dan anak. dari 25 pertanyaan, rata rata peserta bisa menjawab 12 dengan nilai mean 49,3. setelah pemaparan materi, rata-rata peserta bisa menjawab 19 , dengan nilai mean 75,2 terjadi peningkatan skor pengtahuan 25,9. Dengan pertambahan skor setelah diberikan penyuluhan tentang stunting, mak diharapkan terjadi perubahan perilaku pada para generasi muda, khususnya peserta webinar. Perubahan perilaku yang diharapkan disini adalah para generasi muda bersedia menyebarkan ilmunya tentang pencegahan stunting kepada masyarakat secaa umum, dan secara khusus kepada ibu hamil, menyusui, dan keluarga yang mempunyai anak dibawah dua tahun. Penelitian yang dilakukan oleh Rachman mengatakan bahwa pemberian pendidikan gizi pada ibu mempunyai pengaruh yang signifikan terhadap peningkatan pengetahuan ibu tentang pencegahan stunting pada golden peiode (Rachmah et al., 2020). Semakin banyak mahasiswa /generasi muda yang ikut penyuluhan dan menyebarkan ilmunya kepada masyarakat / ibu yang mempunyai anak baduta/ibu menyusui, maka ibu tersebut mengetahui cara memenuhi gizi bagi keluarga terutama pada bayi/anak baduta, sehingga kejadian kekurangan gizi bisa dihindari. Selain menyebarkan ilmu terkait pencegahan stunting, generasi muda diharapkan menerapkan pola hidup bersih dan sehat dimasa pandemi covid ini, menjadi role model bagi masyarakat, tidak merokok, tidak mengkonsumsi narkoba, tidak melakukan seks bebas, dan yang paling penting adalah rajin belajar untuk meningkatkan kompetensinya, sehingga kelak jika sudah menyelesaikan studinya, bisa langsung berkontribusi membantu pemerintah dalam mengisi pembangunan dan menjadi insan unggul dan berkarakter.

\section{KESIMPULAN}

Penyuluhan kesehatan tentang pencegahan stunting terbukti meningkatkan pengetahuan peserta penyuluhan, terbukti ada peningkatan skor pengetahuan dari mean sebelum penyuluhan adalah 49,3 dan nilai mean setelah penyuluhan adalah 75,2, terjadi peningkatan skor 25,9. Dengan peningkatan skor tersebut, diharapkan para generasi muda mampu berkontribusi membantu pemerintah menurunkan kejadian stunting, dengan cara berperilaku hidup bersih dan sehat (PHBS), tidak merokok, tidak menggunakan narkoba, tidak melakukan seks bebas dan aktif memberikan penyuluhan pada masyarakat tentang pencegahan stunting dengan meningkatkan pengetahuan masyarakat yang mempunyai keluarga dengan ibu hamil. menyusui, anak dibawah usia dua tahun, untuk diberikan asi ekslusif, nutisi yang bergizi sehingga tercapai derajad kesehatan yan baik, tidak ada lagi anak yang menderita stunting jika semua keluarga memberikan gizi yang cukup kepada anaknya sejak dalam kandungan sampai usia dua tahun (1000 hari pertama kehidupan). Perlu kerjasama pihak perguruan tinggi dengan masyarakat agar secara aktif mencerdaskan masyarakat dalam bidang kesehatan, khususnya dalam penanggulangan stunting, bisa dalam bentuk praktek lapangan, pengabdian masyarakat, atau kuliah kerja nyata sehingga diperoleh manfaat yang langsung diterima oleh masyarakat dalam peningkatan pengetahuan. Perlu penelitian yang lebih intensif, peran generasi muda dalam berkontribusi peningkatan pengetahuan masyarakat tentang pencegahan stunting, penelitian terkait PHBS oleh para generasi muda bagaimana hubungan PHBS dengan pencegahan stunting.

\section{UCAPAN TERIMA KASIH}

Penulis mengucapkan terimakasih kepada Ketua GenBI Jakarta Saudara Revi Muhammad Syafei, Ketua Pelaksana Webinar Saudari Hilda Arsyah Eka Putri, Moderator Saudari Olivia Citra Octaviani, serta para pengurus GenBI yang telah menyelenggarakan webinar edukasi Prevent 
Stunting for Golden Generation, dan Mbak Nurul Salamah yang telah membantu mengkoordinasikan semua proses kegiatan Bersama GenBI Jakarta. Penulis juga mengucapkan terimakasih kepada Direktur dan Ketua LPPM Akper Giri Satria Husada, yang telah memberikan kesempatan dan mendukung terselenggaranya kegiatan tersebut, tidak lupa ucapan terimakasih yang sebesar-besarnya penulis sampaikan kepada para mahasiswa yang telah menjadi peserta dalam kegiatan tersebut yang tidak bisa penulis sebutkan satu persatu.

\section{DAFTAR PUSTAKA}

Budiastutik, I., \& Rahfiludin, M. Z. (2019). Faktor Risiko Stunting pada anak di Negara Berkembang. Amerta Nutrition, 3(3),

122-129. http://dx.doi.org/10.20473/amnt.v3i3.2019.122-129

Efrizal, W. (2020). Berdampakkah pandemi covid-19 terhadap stunting di bangka belitung? Jurnal Kebijakan Kesehatan Indonesia, 09(03), 154-157. https://journal.ugm.ac.id/jkki/article/view/58695

Farisa, F. C. (2021). Pemerintah Perpanjang PPKM Mikro 14 Hari, Berlaku 9-22 Maret. KOMPAS, 1-6. https://nasional.kompas.com/read/2021/03/08/16540001/pemerintahperpanjang-ppkm-mikro-14-hari-berlaku-9-22-maret-2021?page=all

Febriani, C. A., Perdana, A. A., \& Humairoh, H. (2018). Faktor kejadian stunting balita berusia 6-23 bulan di Provinsi Lampung. Jurnal Dunia Kesmas, 7(3). https://doi.org/10.33024/jdk.v7i3.507

Hadi, M. I., Kumalasari, M. L. F., \& Kusumawati, E. (2019). Faktor Risiko yang Berhubungan dengan Kejadian Stunting di Indonesia: Studi Literatur. Journal of Health Science and Prevention, 3(2), 86-93. https://doi.org/10.29080/jhsp.v3i2.238

Indonesia, B. (2021). Program Beasiswa Bank Indonesia Untuk Perguruan Tinggi Swasta Tahun 2020. https://www.generasibaruindonesia.com/whatsnew/pts

Izwardy, D. (2020). Studi Status Gizi Balita. In Balitbangkes Kemenkes RI.

Lawaceng, C., \& Rahayu, A. Y. S. (2020). Tantangan Pencegahan Stunting pada Era Adaptasi Baru "New Normal" melalui Pemberdayaan Masyarakat di Kabupaten Pandeglang. Jurnal Kebijakan Kesehatan Indonesia: JKKI, 9(3), 136-146. https://journal.ugm.ac.id/jkki/article/view/57781

Marni. (2020). Peningkatan Pengetahuan tentang Narkoba dan HIV / AIDS di. Indonesian Journal of Community Services, 2(2), 126-134. http://dx.doi.org/10.30659/ijocs.2.2.126134

Promosi Kesehatan. (2020). Stunting Di Era Pandemi Covid-19. Dinas Kesehatan Kota Surakarta, 1-5. https://dinkes.surakarta.go.id/stunting-di-era-pandemi-covid-19/

Rachmah, Q., Indriani, D., Hidayah, S., Adhela, Y., \& Mahmudiono, T. (2020). Pendidikan Gizi Gemar Makan Ikan Sebagai Upaya Peningkatan Pengetahuan Ibu tentang Pencegahan Stunting Di Desa Gempolmanis Kecamatan Sambeng Kabupaten Lamongan Provinsi Jawa Timur Nutrition Education “ Gemar Makan Ikan ” to Increase Mother's Knowledge o. https://doi.org/10.20473/amnt.

Teja, M. (2019). Stunting Balita Indonesia Dan Penanggulangannya. Pusat Penelitian Badan Keahlian DPR RI, XI(22), 13-18. 
Zulaikhah, S. T., Wibowo, J. W., Fuad, M. U., Noerhidayati, E., Cahyono, E. B., \& Abduh, M. S. (2019). Penerapan PHBS dengan peningkatan pengetahuan dan sikap melalui pendekatan keluarga di Desa Gaji Kabupaten Demak. Indonesian Journal of Community Services, 1(2), 126-133. http://dx.doi.org/10.30659/ijocs.1.2.126-133 